\title{
Tunable Superhydrophobic Aluminum Surfaces with Anti-Biofouling and Antibacterial Properties
}

\author{
Henry Agbe, Dilip Kumar Sarkar *(D) and X.-Grant Chen \\ Department of Applied Science, Aluminum Research Center REGAL, University of Quebec at Chicoutimi, \\ Chicoutimi, QC G7H 2B1, Canada; henry.agbe1@uqac.ca (H.A.); xgrant_chen@uqac.ca (X.-G.C.) \\ * Correspondence: dsarkar@uqac.ca; Tel.: +1-418-545-5011 (ext. 5243)
}

Received: 10 September 2020; Accepted: 12 October 2020; Published: 15 October 2020

\begin{abstract}
Surfaces in a hygiene critical environment can become potential reservoirs for transmission of pathogenic infections. Engineering surfaces with the tunable anti-biofouling and antibacterial properties could reduce infections particularly in hospitals and public transport hubs. In the present work, a facile two-step process has been deployed to fabricate a superhydrophobic and antibacterial aluminum surface by chemical etching, followed by passivation with low surface energy octyltriethoxysilane (OTES) molecules. The wettability and antibacterial properties of the OTES passivated aluminum was monotonically tuned by adding quaternary ammonium (QUATs) molecules. An anti-biofouling property of $99.9 \%$ against Staphylococcus aureus, $99 \%$ against Pseudomonas aeruginosa and $99 \%$ against $E$. coli bacteria, was achieved.
\end{abstract}

Keywords: tunable superhydrophobic; anti-biofouling surface; antibacterial property; aluminum

\section{Introduction}

Antibacterial coatings for biomedical implant devices (such as catheters, artificial hip and knee joints, etc.) and high touch surface applications have gained much attention in recent times due to their ability to reduce the prevalence of nosocomial infections [1,2]. Antibacterial coatings may not only prevent biofilm formation, medical impact device failure and post-operative bacterial infections, but also reduce microbial bioburden in hygiene critical environment [2]. It is worthwhile mentioning that pathogenic microorganisms can survive on frequently touched surfaces in our daily life such as door knobs, push plates, etc. for days, weeks and months [1,2]. Thus, surfaces act as hot-spots for transmission of pathogenic infections [2]. To this end, engineering surfaces with antibacterial property has now been acknowledged as an important strategy for reducing microbial bioburden and the prevalence of infections [3]. Among surfaces with antibacterial properties, anti-biofouling and superhydrophobic surfaces seem desirable as they have the ability to inhibit bacterial attachment on surfaces.

Superhydrophobic surfaces possess a static water contact angle (CA) $>150^{\circ}$ with a water roll-off property. In nature, scientists have discovered the unique water roll-off property in several plants, such as lotus leaf. Such a superhydrophobic surface can be fabricated by patterning micro-nano structures, followed by passivation with low surface energy molecules. Various strategies such as photolithography [4], sol-gel [4], plasma etching [5], anodization [6] and chemical etching [7] have been deployed to fabricate superhydrophobic surfaces, which find applications as self-cleaning fabrics, anticorrosion, drag reduction and anti-biofouling surface [8]. Though, superhydrophobic surfaces can repel bacterial adhesion, they fail under long-term exposure [9]. For example, Ivanova et al. [10] utilized femtosecond laser ablation process to fabricate superhydrophobic titanium coatings (with CA of $166^{\circ}$ ), and demonstrated their effectiveness at repelling Pseudomonas aeruginosa (P.A), (Gram -ve) bacterium attachment. However, over long-term exposure $(\sim 18 \mathrm{~h})$, the water roll-off property 
was lost, subsequently leading to both Staphylococcus aureus (S.A), (Gram +ve) and P.A bacterial colonization. Thus, incorporating bactericides in superhydrophobic coating holds promise not only in inducing both anti-biofouling and antibacterial properties, but also for improving their longevity. Again, superhydrophobic coating incorporated with bactericide could minimize uncontrolled bactericide release and subsequent toxicity concerns.

Therefore, designing surfaces with both superhydrophobic and antibacterial properties has recently gained significant interest [11-13]. For example, Chung et al. [12] fabricated a silver-perfluorodecanethiolate coatings on silicon wafer with both superhydrophobic and antibacterial coatings via precipitation method, using perfluorodecanethiol (PFDT) and silver as fluorinated and metal-thiolate complexes precursors, respectively. In a related work, Wang et al. [11] fabricated a superhydrophobic diamond films with both antibacterial and anti-biofouling properties using hot filament chemical vapor deposition and sol-gel perfluorodecyltrichlorosilane (PFTS) molecules passivation. Meanwhile, Zhang et al. [13] reported a Ag/Cu bimetallic coatings fabricated using a galvanic replacement reaction and thermal oxidation processes. This coating exhibited both superhydrophobic and antibacterial properties, but the bacterial repellent property was not reported. It is reported that fluorosilane molecules and leachable bactericides such as $\mathrm{Ag}$ and $\mathrm{Cu}$ may be toxic to the ecosystem [14]. For example, Ag and $\mathrm{Cu}$ at $6.1 \mathrm{ppm}(56.5 \mu \mathrm{M})$ and $2.61 \mathrm{ppm}(41.1 \mu \mathrm{M})$ were reported to be toxic to Zebrafish embryos [15]. Again, fluorinated compounds have been implicated in sporadic outbreaks of respiratory illness characterized by dyspnea, cough and chest pain [16]. Thus, there is an urgent need for alternative biocompatible low surface energy molecule and non-toxic bactericides (such as quaternary ammonium (QUATs) molecules commonly used as disinfectants for sanitizing hospital environment) to fabricate tunable superhydrophobic and antibacterial coatings.

In the present work, a facile two-step process is deployed to fabricate superhydrophobic and antibacterial aluminum surface by chemical etching, followed by passivation with low surface energy hydrocarbon of octyltriethoxysilane (OTES) molecules. To the best of our knowledge, this is the first report on OTES-QUATs coatings with tunable antibacterial and bacterial repellent properties. While the water CA of most above mentioned coatings [11-13] are well above $150^{\circ}$ and the coatings exhibited bacterial repellent and antibacterial properties, their tunable properties have not been systematically studied yet. It should be mentioned that a tunable superhydrophobic coating could be tailored for some specific applications, such as hydrophobic and antibacterial coatings for medical implants or superhydrophobic and antibacterial coatings for a cooling tower or frequently touched surfaces. Again, such coatings could improve the overall longevity of antibacterial properties even after the loss of superhydrophobicity. In the present study, the water roll-off property is monotonically tuned from superhydrophobic to hydrophilic surface by increasing the concentration of the QUATs. Furthermore, the excellent antibacterial and anti-biofouling properties, as well as their synergistic effects are demonstrated.

\section{Materials and Methods}

A 1 inch $\times 2$ inches $\mathrm{Al}$ (AA6061) was ultrasonically degreased in a soapy solution, followed by chemical etching in $30 \mathrm{wt} . \% \mathrm{HCl}$ at $55^{\circ} \mathrm{C}$ for $3 \mathrm{~min}$. A total of $50 \mathrm{~mL}$ ethanol was taken in a beaker and $1000 \mu \mathrm{L}$ of $3.0 \mathrm{M}$ OTES added while stirring using a magetic bar, on a hot plat of temperature of $25^{\circ} \mathrm{C}$, to prepare the mixed solution of OTES. Furthermore $0.01 \mathrm{M}$ of QUAT was added drop by drop in the solution to obtain the mixed solution of OTES-QUAT. The amount of OTES was kept contant and the $0.01 \mathrm{M}$ QUAT added in such as way that the molar ratio of QUAT: OTES varies between 0 to $54 \times 10^{-4}$, according to Table S1 (shown in the Supporting Information, Table S1). The OTES-QUATs suspension was then sonicated for $15 \mathrm{~min}$ for dispersion. Subsequently, the etched $\mathrm{Al}$ substrates were immersed in these solutions for $30 \mathrm{~min}$ for the passivation. Furthermore, the passivated aluminum substrates were dried in the oven $100{ }^{\circ} \mathrm{C}$ in the air atmosphere for $2 \mathrm{~h}$ to remove residual solvents. 


\subsection{Sample Characterization}

The morphological and elemental characterizations of the samples were analyzed using scanning electron microscopy (SEM, JEOL JSM-6480 LV, Pleasanton, CA, USA), equipped with energy dispersive X-ray spectroscopy (EDS, JEOL, Pleasanton, CA, USA). The chemical compositions were analysed by attenuated total reflection-fourier transform infrared (ATR, Agilent Technologies Cary 630 FTIR, Santa Clara, CA, USA). In addition, the wetting characteristics of the samples were determined by measuring both static and dynamic contact angles (CA) using a First Ten Angstrom Contact angle goniometer at five positions on each substrate using $10 \mathrm{~mL}$ deionized water drop. The dynamic contact angle was measured by holding the water droplet with a stationary needle in contact with the sample surface and moving the goniometer stage in one direction. The surface roughness of the coatings were measured using an optical profilometer (MicroXAM-100 HR 3D surface profilometer, NANOVEA, Irvine, CA, USA).

\subsection{Antibacterial Assay}

Antibacterial activity was determined by both anti-biofouling and disk diffusion assays. Using bacterial repellent assay, bacterial strains: Staphylococcus aureus (ATCC 6538), Escherichia coli (ATCC 8739), and Pseudomonas aeruginosa (ATCC 9027)), were grown overnight from frozen $\left(-80^{\circ} \mathrm{C}\right.$ ) glycerol stock in tryptic soy broth (TSB) (Hardy Diagnostics) at $37{ }^{\circ} \mathrm{C}$, and then passaged on fresh TSB $\left(37^{\circ} \mathrm{C}\right)$ to obtain bacterial cell density of $10^{8}$ colony forming units/milliliter (CFU)/mL. Bacterial cell density was determined by measuring the optical density (OD) at $625 \mathrm{~nm}$ wavelength. Static bacterial adhesion experiments were conducted following a prescribed protocol elsewhere [17]. Briefly, two $250 \mathrm{~mL}$ sterile beakers were filled with $99 \mathrm{~mL} 10 \mathrm{mM}$ phosphate buffer solution (PBS) (pH 7.5 $+/-0.3$ at $25^{\circ} \mathrm{C}$.) and $1 \mathrm{~mL}$ bacterial culture. Subsequently, test samples, namely 1 inch $\times 2$ inches etched $\mathrm{Al}$ substrates (used as blank) and OTES-QUATs passivated Al substrates were placed separately in the beakers. Samples were then incubated for $3 \mathrm{~h}$ at $37^{\circ} \mathrm{C}$. Next, samples were rinsed in PBS to remove non-adherent bacteria, which were subsequently transferred into a set of $50 \mathrm{~mL}$ sterile beakers (containing PBS), and sonicated on ice for $10 \mathrm{~min}$ to remove adherent bacteria. Finally, the bacterial suspensions were serially diluted, and plated on tryptic soy agar TSA, followed by an aerobic incubation at $37^{\circ} \mathrm{C}$ for $24 \mathrm{~h}$. Positive controls were performed for $t=0$ and $t=3 \mathrm{~h}$ to ascertain bacterial viability. All experiments were performed in triplicate and on fresh bacterial inoculum. Relative bacterial adhesion was calculated as $[(\mathrm{A}-\mathrm{B}) / \mathrm{A} \times 100 \%]$, where $\mathrm{A}=\mathrm{CFU} / \mathrm{cm}^{2}$ of adherent bacteria on etched $\mathrm{Al}$ substrates and $\mathrm{B}=\mathrm{CFU} / \mathrm{cm}^{2}$ of adherent bacteria on OTES-QUATs passivated sample. Data were analyzed by ANOVA with the Tukey-Kramer multiple comparison test. Data were considered significant at $p<0.05$.

Regarding the disk diffusion assays, bacterial strains were grown overnight to obtain $10^{8} \mathrm{CFU} / \mathrm{mL}$ as described above. Kirby Bauer disk diffusion assay was used as described elsewhere [18]. Briefly, sterile swab was used to inoculate Mueller Hinton Agar (Hardy Diagnostics) films by streaking to obtain a bacterial lawn. Subsequently, $20 \mu \mathrm{L}$ QUATs soaked Whatman filter papers $(6 \mathrm{~mm}$ diameter) were inserted on the agar media. Finally, the agar plates were aerobically incubated at $37^{\circ} \mathrm{C}$ for $24 \mathrm{~h}$. Experiments were repeated and in triplicate, on different days with fresh bacterial cell suspensions. All microbiology experiments related to the following bacterial cell culture: Staphylococcus aureus-(ATCC 6538), Pseudomonas aeruginosa (ATCC9027) and Escherichia coli (ATCC 8739) were obtained from Hardy Diagnostics, and conducted at the microbiology laboratory of our industrial partner and commenced subject to the ethical approval of their ethics committee (https://a3surfaces.com/en/). 


\section{Results and Discussion}

\subsection{Morphological and Chemical Analysis}

In Figure 1a, I-III show the ATR-FTIR spectra of octyltriethoxysilane molecules passivated etched Al substrate (OTES/Al); octyltriethoxysilane and quaternary ammonium molecules passivated etched Al substrate (OTES-QUATs/Al); and quaternary ammonium molecules passivated etched aluminum (QUATs/Al), respectively. The peak at $3445 \mathrm{~cm}^{-1}$, represents the $\mathrm{O}-\mathrm{H}$ and $\mathrm{N}-\mathrm{H}$ stretching modes [19]. While those at 2955, 2920 and $2853 \mathrm{~cm}^{-1}$ can be assigned to asymmetric $\mathrm{CH}_{3}$ groups; and symmetric $\mathrm{CH}_{2}$ and asymmetric $\mathrm{CH}_{2}$ vibration modes [20,21]. Again, the asymmetrical stretching vibration of the Si-O-Si molecules are located in the $1060-1100 \mathrm{~cm}^{-1}$ bands. Additionally, $1646-898 \mathrm{~cm}^{-1} \mathrm{can} \mathrm{be}^{-}$ assigned to the $\mathrm{C}-\mathrm{N}$ and $\mathrm{C}-\mathrm{H}$ stretching modes of QUATs [22,23], (Supporting Information can be found in Figure S1). Finally, the $1080 \mathrm{~cm}^{-1}$ peak corresponds to the asymmetric $\mathrm{Si}-\mathrm{O}-\mathrm{CH}_{2} \mathrm{CH}_{3}$ mode of OTES-QUATs [20]. It is interesting to note that the increasing intensity of this peak of OTES-QUATs/Al compared to OTES/Al (Figure 1a) (II vs. I)) is due to symmetric and asymmetrical stretching vibration overlaps from both the molecules of OTES and QUATs; and the resulting non-hydrolysable reaction [20]. It has been suggested that QUATs covalently bonds to alkyl chains of siloxane [19] through a non-hydrolysable Si-O-C bonding. Therefore, on the addition of QUATs, the alkyl group of nitrogen $\left(\mathrm{N}^{+}\right)-\left(\mathrm{CH}_{3}\right)_{3}$ covalently bonds with the octyl chains of the octyltriethoxysilane (OTES) molecules through a non-hydrolysable reaction. Ref. [24], as schematically modelled in Figure 1b(II).

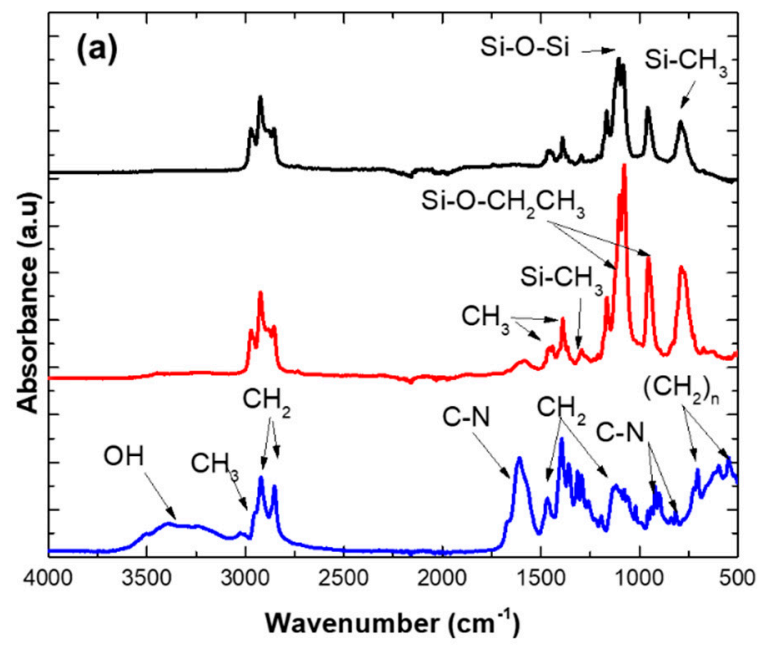

(b)

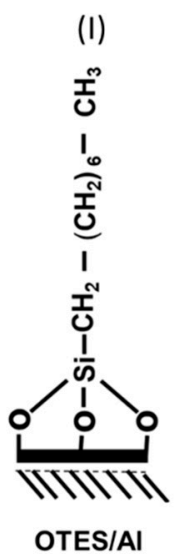

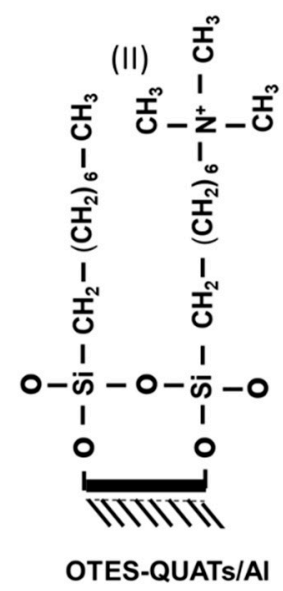

Figure 1. (a) Attenuated total reflection-fourier transform infrared (ATR-FTIR) spectra of: (I) Octyltriethoxysilane molecules passivated etched Al substrate (OTES/Al); (II) octyltriethoxysilane and quaternary ammonium molecules passivated etched Al substrate (OTES-QUATs/Al); (III) quaternary ammonium molecules passivated etched aluminum (QUATs/Al). (b) Schematic model of: (I) OTES on etched aluminum (OTES/Al); (II) formation of OTES-QUATs on etched Al, along with (OTES/Al).

In addition to the FTIR, SEM and EDS (Figure 2a-d) were performed to study the morphological and the elemental composition of OTES-QUATs molecules passivated etched aluminum, respectively. EDS spectra show the presence of $\mathrm{C}, \mathrm{N}, \mathrm{O}, \mathrm{Al}, \mathrm{Si}$ and $\mathrm{Cl}$, with their corresponding $\mathrm{K}_{\alpha}$ peaks at $0.28,0.39$, $0.53,1.49,1.74$ and $2.62 \mathrm{keV}$, respectively. As shown in the inset in Figure $2 \mathrm{a}$, chemical etching results in a topologically terraced micro and nano-features with surface rms roughness and contact angle (CA) of $6.2 \pm 1.5 \mu \mathrm{m}$ and $16^{\circ} \pm 0.2^{\circ}$ (Supporting Information, Table S2), respectively, which is similar to those previously reported [25]. These small faceted and labyrinth micro-nano features can trap air through the dispersed protrusions of asperities, reducing solid droplet contact to repel droplets over the entrapped air layers [26]. However, OTES-QUATs/Al samples exhibited a roughness of $5.8 \pm 0.5 \mu \mathrm{m}$ and a CA of $153^{\circ} \pm 3.7^{\circ}$ (shown in the Supporting Information, Table S2). Similarly, the OTES/Al 
samples showed a roughness of $6.5 \pm 0.5 \mu \mathrm{m}$, and a CA of $161^{\circ} \pm 2.3^{\circ}$ (Supporting Information can be found in Table S2). It can be noted that the roughness of the etched and passivated samples were around $6 \mu \mathrm{m}$.
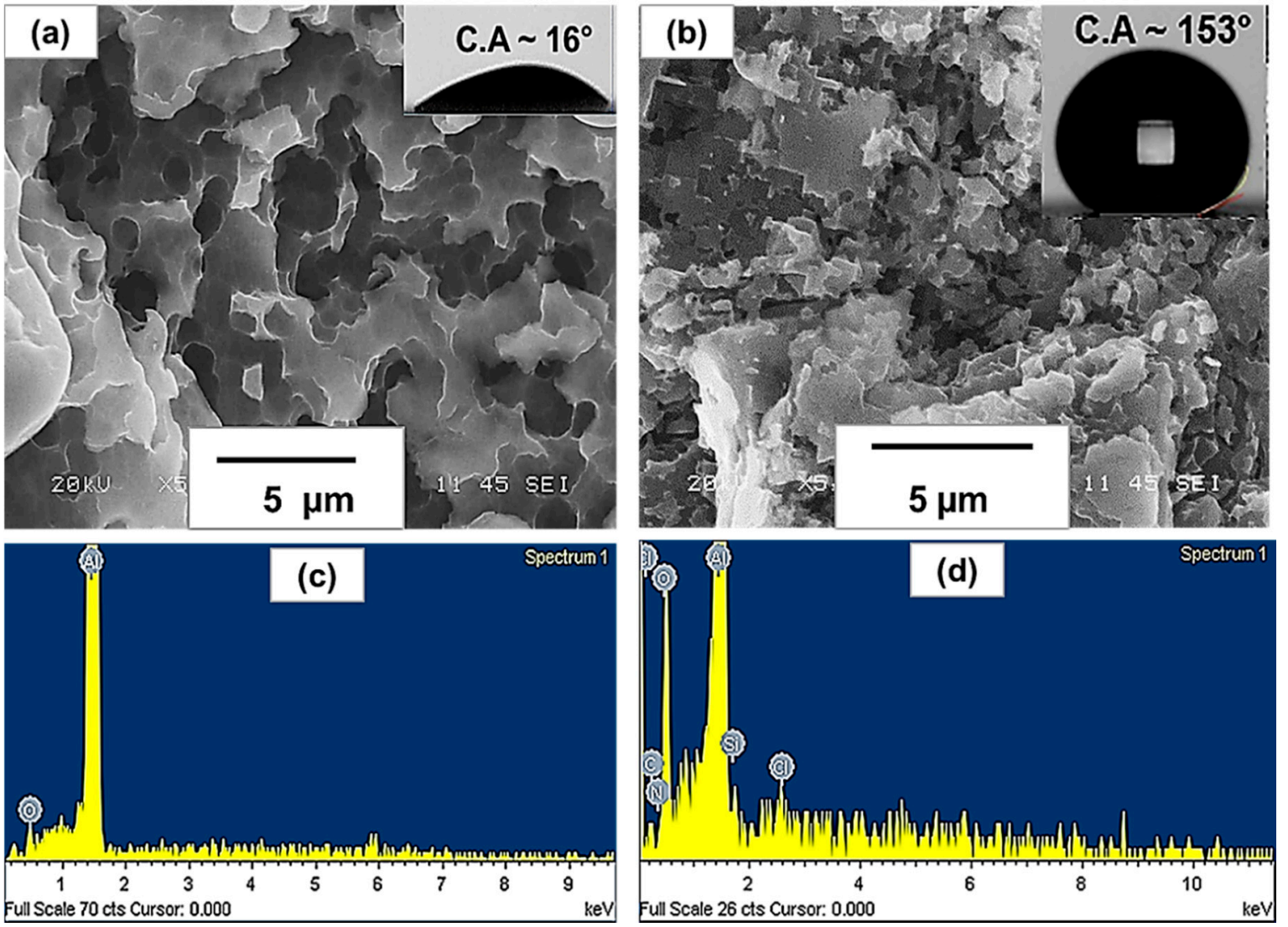

Figure 2. (a-d) SEM images and EDS spectra of etched Al substrate and OTES-QUATs/Al, respectively. The insets also show the images of water drop on the respective surfaces with their contact angles.

Note that the superhydrophobicity is due to combined effects of low surface energy OTES molecules and micro-nano roughness of etched aluminum substrates. It is well known that the micro-nano pattern on the surface allows large amount of air to be entrapped into the pattern, while the low surface energy molecules inhibit the interaction with water $[27,28]$. Therefore, having a $\mathrm{CA}>160^{\circ}$, it is reasonable to assume that water drops on OTES/Al samples would roll-off easily. However, by increasing molar ratio of QUATs/OTES, the wettability of OTES/Al sample was monotonically converted from superhydrophobic to hydrophilic. The trend continued with loss of superhydrophobicity (Figure 3). It should be mentioned that QUATs are amphiphilic surfactants having hydrophilic head groups (nitrogen and anion halide), covalently attached to four functional hydrophobic alkyl groups. At a high hydrophilic density $\left(\mathrm{N}^{+}-\mathrm{Cl}^{-}, \mathrm{O}^{-}-\mathrm{H}^{+}\right.$etc. $)$, surface chemistry is altered, decreasing OTES hydrophobic groups, thus lowering CA. 


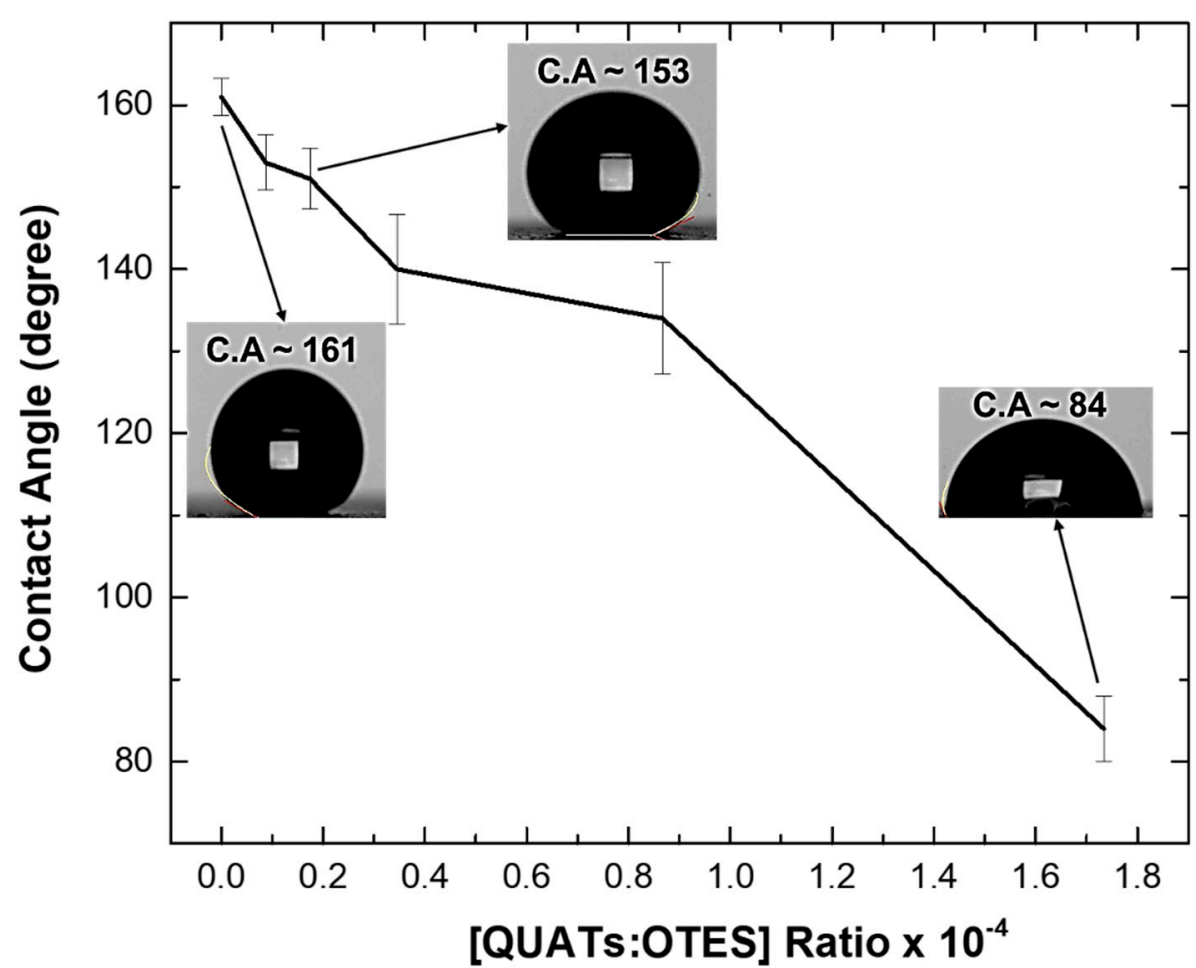

Figure 3. Variation in contact angle as a function of QUATs/OTES molar ratio.

Compared to $\mathrm{CA}$, contact angle hysteresis $(\mathrm{CAH})$ exhibited a linear relationship with increasing molar ratio of [QUATs: OTES] (shown in the Supporting Information, Table S2). OTES passivated $\mathrm{Al}$ showed a $\mathrm{CAH}$ of $9^{\circ} \pm 3.6^{\circ}$, where droplet becomes unstable and starts to roll-off on the surfaces. However, as molar ratio of [QUATs: OTES] increased, CAH gradually increased to $15^{\circ} \pm 5^{\circ}$ until droplet stuck on the surface with large values of CAH (Supporting Information, can be found in Table S2).

\subsection{Antibacterial Activity}

Antibacterial property was studied by both disk diffusion and bacterial adhesion assays. Note that disk diffusion describes antibacterial assay that utilizes the diffusion of antimicrobial agents to inhibit the growth of microorganisms. The region surrounding antimicrobial agent, where microbial growth is inhibited is called the zone of inhibition (ZOI). The larger the ZOI, the better and effective the antimicrobial agent. It should be mentioned that QUATs are membrane-active agents that interact with the cytoplasmic membrane of bacteria and lipids of viruses [29]. They are very effective antimicrobial agent and first-line defense disinfectants against a wide variety of pathogenic microorganisms, used generally for sanitizing hospital environments [30]. As shown in Figure 4a, the disk diffusion assay results for S.A showed a zone of inhibition (ZOI) of $39 \pm 0.8,34 \pm 1.6$, and $12.0 \pm 0.5$ for ethanoic QUATs, OTES-QUATs and OTES, respectively. Similar trends were also observed for the other bacteria, namely P.A and E. coli, as given in Table 1. Note that the QUAT only partially bonded to the OTES, thus the remaining QUAT leached, forming the zone of inhibition. Again, it should be mentioned that the ZOI for OTES is due to the antibacterial effect of ethanol [31]. Though the antimicrobial mechanism for QUATs is unclear [32], it is generally believed that the electrostatic interaction between the positively charged nitrogen moiety $\left(\mathrm{N}^{+}\right)$in QUATs and the negatively charged intracellular molecules (such as phospholipid bilayer, RNA and DNA) leads to cell membrane and cytoplasmic (lipid or protein) perturbation resulting in subsequent bacterial death [32,33]. Again, due to its amphiphilic nature, hydrophobic tails can interact electrostatically with the hydrophobic groups of the phospholipid bilayer and in the process, disrupt the bacterial membrane core, leading to bacterial death [34]. 

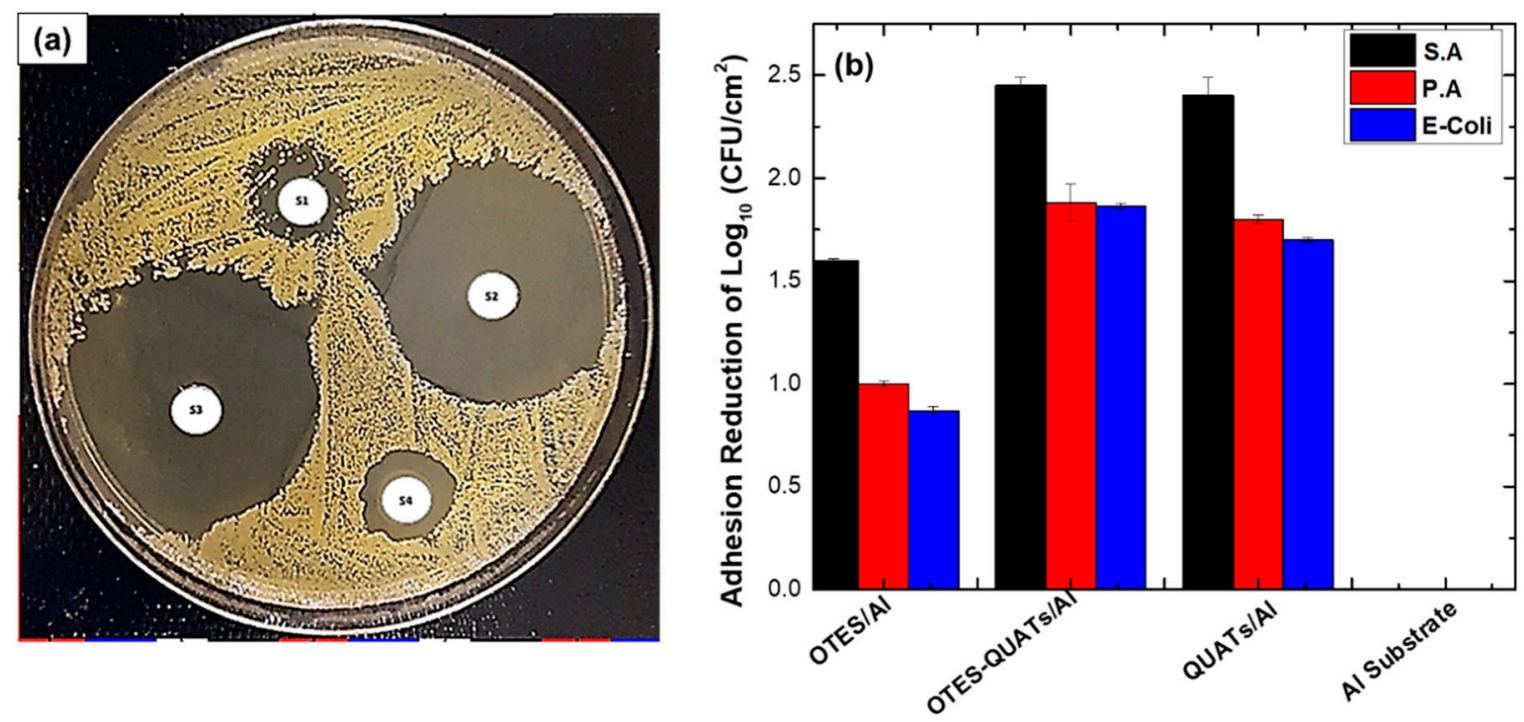

Figure 4. (a) Disk diffusion assay of ethanoic solution of: OTES (Region S1); OTES-QUATs (region S2); (QUATs) (region S3) and Ethanol (region S4), treated against Staphylococcus aureus bacterium. (b) Graphical representation of adhesion reduction of Staphylococcus aureus, Pseudomonas aeruginosa and Escherichia coli on OTES/Al, OTES-QUATs/Al, QUATs/Al and etched Al substrate.

Table 1. Disk diffusion assay results of OTES-QUATs samples.

\begin{tabular}{cccc}
\hline & \multicolumn{2}{c}{ Mean Diameter Zone of Inhibition (ZOI) (mm) } \\
\cline { 2 - 4 } Agent & $\begin{array}{c}\text { Gram-Positive } \\
\text { Bacterium }\end{array}$ & Gram-Negative Bacteria \\
\cline { 2 - 4 } & $\begin{array}{c}\text { Staphylococcus aureus } \\
\text { (ATCC 6538) }\end{array}$ & P. aeruginosa (ATCC 9027) & E. coli (ATCC 7839) \\
\hline OTES & $12.0 \pm 0.5$ & $11.0 \pm 1.0$ & $11.0 \pm 1.3$ \\
OTES-QUATs & $34 \pm 1.6$ & $22 \pm 1.4$ & $25 \pm 0.9$ \\
QUATs & $39 \pm 0.8$ & $24 \pm 1.2$ & $27 \pm 0.8$ \\
Ethanol & $13 \pm 0.8$ & $12 \pm 0.5$ & $12 \pm 0.5$ \\
\hline
\end{tabular}

Figure $4 \mathrm{~b}$, shows the graphical representation of bacterial adhesion reduction $/ \mathrm{cm}^{2}$ for the model bacteria under study (shown in the Supporting Information, Table S3). OTES passivated aluminum sample showed a bacterial adhesion reduction factor of $1.6(98 \%), 1.0(90 \%)$ and $0.9(87 \%)$ for S.A, P.A and E-Coli respectively, compared to etched Al substrate. Contrarily, OTES-QUATs/Al samples exhibited a $\log$ reduction of $2.45(99.9 \%), 1.88(99 \%)$ and $1.85(99 \%)$ for the same bacteria, respectively. Similarly, QUATs/Al sample, showed a 2.39 (99.6\%), 1.79 (98.4\%) and 1.69 (98.0\%) log reduction. However, on etched $\mathrm{Al}$ substrate (used as control), there were no significant reduction in bacterial colony. Compared to OTES/Al samples, the OTES-QUATs/Al samples were superior and exhibited two order of magnitude higher by reduction factor due to the synergistic effects of QUATs and OTES.

It is worthwhile mentioning that the OTES-QUATs passivated etched aluminum compares favorably to other superhydrophobic coatings/surfaces reported in the literature [11,12]. For example, in the work of Chung et al. [12], a silver-perfluorodecanethiolate superhydrophobic coatings on silicon wafer exhibited bacterial adhesion reduction factor of $77 \%$. Additionally, in a related study by Wang et al. [11] a perfluorodecyltrichlorosilane superhydrophobic diamond films showed a bacterial adhesion reduction of $90 \%$ to $99 \%$. However, direct comparison of reported results in the literature must be treated with caution, due to possible different experimental conditions. In this study the superhydrophobic surfaces fabricated from a biocompatible siloxane precursor and a commonly used disinfectant (QUATs), which exhibits an excellent bacterial adhesion reduction factor of $99.9 \%$ against S.A, (Gram +ve) bacterium, and 99\% against both P.A and E. coli (Gram -ve) bacteria, respectively, 
appears promising. In general, the OTES-QUATs on aluminum surface exhibits both anti-biofouling and antibacterial properties due to the combined effects of low energy OTES and micro-nano roughness and the presence of QUATs, respectively. As a further study, OTES-QUATs solution was drop cast on cotton fiber and tissue paper and exhibited water roll-off properties (Videos S1 and S2), suggesting that superhydrophobic OTES-QUATs could be explored in fabricating anti-biofouling healthcare consumables such as nose masks, bedsheets and medical scraps.

\section{Conclusions}

In this study, aluminum surfaces with tunable superhydrophobic, anti-biofouling and antibacterial properties were described. These surfaces were fabricated by chemical etching of aluminum substrates, followed by passivation with OTES-QUATs molecules. The OTES-QUATs solution exhibited excellent antibacterial activity, with a ZOI of $34 \pm 1.6,22 \pm 1.4$, and $25 \pm 0.9$, against Staphylococcus aureus, Pseudomonas aeruginosa and Escherichia coli, respectively. Similarly, OTES-QUATs on aluminum surface showed superior anti-biofouling property with a $99.9 \%$ bacterial adhesion reduction factor for Staphylococcus aureus, 99\% for Pseudomonas aeruginosa and 99\% for E. coli bacteria, due to both superhydrophobic nature of OTES and antibacterial nature of OUATs molecules. Overall, the antibacterial properties of the OTES-QUATs passivated aluminum looks promising and can be regarded as an adjunct to hand hygiene for reducing potential bacterial infections in hygiene critical environments.

Supplementary Materials: The following are available online at http:/www.mdpi.com/2079-6412/10/10/982/s1, Figure S1: ATR-FTIR spectra, Table S1: QUATs: OTES molar ratio, Table S2: Variation of surface roughness, contact angle (CA) and contact angle hysteresis, (CAH), Table S3: Antibacterial activity, Video S1: OTES-QUATs treated cotton fiber, Video S2: OTES-QUATs treated tissue paper.

Author Contributions: Conceptualization, D.K.S. and H.A.; methodology, H.A. and D.K.S.; software, H.A.; validation, D.K.S.; formal analysis, H.A. and D.K.S.; investigation, H.A.; resources, X.-G.C.; data curation, H.A.; writing-original draft preparation, H.A.; writing—review and editing, D.K.S., X.-G.C. and H.A.; visualization, H.A.; supervision, D.K.S. and X.-G.C.; project administration, X.-G.C.; funding acquisition, X.-G.C. and D.K.S. All authors have read and agreed to the published version of the manuscript.

Funding: This research was funded Fonds de recherche du Québec-Nature et technologies (FRQNT) under the grant number 2018-LU-210883.

Conflicts of Interest: The authors declare no conflict of interest.

\section{References}

1. Vrana, N.E. Biomaterials and Immune Response: Complications, Mechanisms and Immunomodulation; CRC Press: Boca Raton, FL, USA, 2018.

2. Walker, J. Decontamination in Hospitals and Healthcare; Woodhead Publishing: Cambridge, UK, 2019.

3. Kramer, A.; Schwebke, I.; Kampf, G. How long do nosocomial pathogens persist on inanimate surfaces? A systematic review. BMC Infect. Dis. 2006, 6, 130. [CrossRef]

4. Öner, D.; McCarthy, T.J. Ultrahydrophobic Surfaces. Effects of Topography Length Scales on Wettability. Langmuir 2000, 16, 7777-7782.

5. Olde Riekerink, M.B.; Terlingen, J.G.; Engbers, G.H.; Feijen, J. Selective Etching of Semicrystalline Polymers: CF4 Gas Plasma Treatment of Poly(ethylene). Langmuir 1999, 15, 4847-4856. [CrossRef]

6. Momen, G.; Farzaneh, M.; Jafari, R. Wettability behaviour of RTV silicone rubber coated on nanostructured aluminium surface. Appl. Surf. Sci. 2011, 257, 6489-6493. [CrossRef]

7. Safaee, A.; Sarkar, D.K.; Farzaneh, M. Superhydrophobic properties of silver-coated films on copper surface by galvanic exchange reaction. Appl. Surf. Sci. 2008, 254, 2493-2498. [CrossRef]

8. Brassard, J.-D.; Sarkar, D.K.; Perron, J. Synthesis of monodisperse fluorinated silica nanoparticles and their superhydrophobic thin films. ACS Appl. Mater. Interfaces 2011, 3, 3583-3588. [CrossRef]

9. Liu, S.; Zheng, J.; Hao, L.; Yegin, Y.; Bae, M.; Ulugun, B.; Taylor, T.M.; Scholar, E.A.; Cisneros-Zevallos, L.; Oh, J.K.; et al. Dual-Functional, Superhydrophobic Coatings with Bacterial Anticontact and Antimicrobial Characteristics. ACS Appl. Mater. Interfaces 2020, 12, 21311-21321. [CrossRef] 
10. Fadeeva, E.; Truong, V.K.; Stiesch, M.; Chichkov, B.N.; Crawford, R.J.; Wang, J.; Ivanova, E.P. Bacterial retention on superhydrophobic titanium surfaces fabricated by femtosecond laser ablation. Langmuir 2011, 27, 3012-3019. [CrossRef]

11. Wang, T.; Huang, L.; Liu, Y.; Li, X.; Liu, C. Robust Biomimetic Hierarchical Diamond Architecture with a Self-Cleaning, Antibacterial, and Antibiofouling Surface. ACS Appl. Mater. Interfaces 2020, 12, 24432-24441. [CrossRef]

12. Chung, J.-S.; Kim, B.G.; Shim, S.; Kim, S.E.; Sohn, E.H.; Yoon, J.; Lee, J.C. Silver-perfluorodecanethiolate complexes having superhydrophobic, antifouling, antibacterial properties. J. Colloid Interface Sci. 2012, 366, 64-69. [CrossRef]

13. Zhang, M.; Wang, P.; Sun, H.; Wang, Z. Superhydrophobic surface with hierarchical architecture and bimetallic composition for enhanced antibacterial activity. ACS Appl. Mater. Interfaces 2014, 6, 22108-22115. [CrossRef] [PubMed]

14. Hays, H.L.; Mathew, D.; Chapman, J. Fluorides and Fluorocarbons Toxicity; StatPearls Publishing: Treasure Island, FL, USA, 2020.

15. Yen, H.-J.; Horng, J.L.; Yu, C.H.; Fang, C.Y.; Yeh, Y.H.; Lin, L.Y. Toxic effects of silver and copper nanoparticles on lateral-line hair cells of zebrafish embryos. Aquat. Toxicol. 2019, 215, 105273. [CrossRef] [PubMed]

16. Centers for Disease Control and Prevention. Severe acute respiratory illness linked to use of shoe sprays-Colorado, November 1993. MMWR. Morb. Mortal. Wkly. Rep. 1993, 42, 885.

17. Meier, M.; Dubois, V.; Seeger, S. Reduced bacterial colonisation on surfaces coated with silicone nanostructures. Appl. Surf. Sci. 2018, 459, 505-511. [CrossRef]

18. Bahrami, A.; Mokarram, R.R.; Khiabani, M.S.; Ghanbarzadeh, B.; Salehi, R. Physico-mechanical and antimicrobial properties of tragacanth/hydroxypropyl methylcellulose/beeswax edible films reinforced with silver nanoparticles. Int. J. Biol. Macromol. 2019, 129, 1103-1112. [CrossRef]

19. Wu, K.-H.; Wang, J.C.; Huang, J.Y.; Huang, C.Y.; Cheng, Y.H.; Liu, N.T. Preparation and antibacterial effects of $\mathrm{Ag} / \mathrm{AgCl}$-doped quaternary ammonium-modified silicate hybrid antibacterial material. Mater. Sci. Eng. C 2019, 98, 177-184. [CrossRef]

20. Hasan, A.; Pandey, L.M. Kinetic studies of attachment and re-orientation of octyltriethoxysilane for formation of self-assembled monolayer on a silica substrate. Mater. Sci. Eng. C 2016, 68, 423-429. [CrossRef]

21. Zhang, F.; Srinivasan, M. Self-assembled molecular films of aminosilanes and their immobilization capacities. Langmuir 2004, 20, 2309-2314. [CrossRef]

22. Li, S.-D.; Li, P.W.; Yang, Z.M.; Peng, Z.; Quan, W.Y.; Yang, X.H.; Yang, L.; Dong, J.J. Synthesis and characterization of chitosan quaternary ammonium salt and its application as drug carrier for ribavirin. Drug Deliv. 2014, 21, 548-552. [CrossRef]

23. Kurrey, R.; Deb, M.K.; Shrivas, K. Surface enhanced infra-red spectroscopy with modified silver nanoparticles (AgNPs) for detection of quaternary ammonium cationic surfactants. New J. Chem. 2019, 43, 8109-8121. [CrossRef]

24. Poberžnik, M.; Kokalj, A. Implausibility of bidentate bonding of the silanol headgroup to oxidized aluminum surfaces. Appl. Surf. Sci. 2019, 492, 909-918. [CrossRef]

25. Escobar, A.M.; Llorca-Isern, N. Superhydrophobic coating deposited directly on aluminum. Appl. Surf. Sci. 2014, 305, 774-782. [CrossRef]

26. Hosono, E.; Fujihara, S.; Honma, I.; Zhou, H. Superhydrophobic perpendicular nanopin film by the bottom-up process. J. Am. Chem. Soc. 2005, 127, 13458-13459. [CrossRef] [PubMed]

27. Ma, W.; Ding, Y.; Zhang, M.; Gao, S.; Li, Y.; Huang, C.; Fu, G. Nature-inspired chemistry toward hierarchical superhydrophobic, antibacterial and biocompatible nanofibrous membranes for effective UV-shielding, self-cleaning and oil-water separation. J. Hazard. Mater. 2020, 384, 121476. [CrossRef]

28. Brassard, J.-D.; Sarkar, D.K.; Perron, J. Studies of drag on the nanocomposite superhydrophobic surfaces. Appl. Surf. Sci. 2015, 324, 525-531. [CrossRef]

29. Gerba, C.P. Quaternary ammonium biocides: Efficacy in application. Appl. Environ. Microbiol. 2015, 81, 464-469. [CrossRef]

30. Jennings, M.C.; Buttaro, B.A.; Minbiole, K.P.; Wuest, W.M. Bioorganic investigation of multicationic antimicrobials to combat QAC-resistant Staphylococcus aureus. ACS Infect. Dis. 2015, 1, 304-309. [CrossRef]

31. Batzing, B.L. Microbiology: An Introduction; Brooks/Cole: Pacific Grove, CA, USA, 2002. 
32. Knauf, G.A.; Cunningham, A.L.; Kazi, M.I.; Riddington, I.M.; Crofts, A.A.; Cattoir, V.; Trent, M.S.; Davies, B.W. Exploring the antimicrobial action of quaternary amines against Acinetobacter baumannii. MBio 2018, 9, e02394-17.

33. Zeng, M.; Xu, J.; Luo, Q.; Hou, C.; Qiao, S.; Fu, S.; Fan, X.; Liu, J. Constructing antibacterial polymer nanocapsules based on pyridine quaternary ammonium salt. Mater. Sci. Eng. C 2020, 108, 110383. [CrossRef]

34. Jiao, Y.; Niu, L.N.; Ma, S.; Li, J.; Tay, F.R.; Chen, J.H. Quaternar ammonium-based biomedical materials: State-of-the-art, toxicological aspects and antimicrobial resistance. Prog. Polym. Sci. 2017, 71, 53-90. [CrossRef]

Publisher's Note: MDPI stays neutral with regard to jurisdictional claims in published maps and institutional affiliations.

(C) 2020 by the authors. Licensee MDPI, Basel, Switzerland. This article is an open access article distributed under the terms and conditions of the Creative Commons Attribution (CC BY) license (http://creativecommons.org/licenses/by/4.0/). 